\title{
Kepribadian dan Self-Regulated Learning
}

\author{
Personality and Self-Regulated Learning
}

\author{
Asina Christina Rosito ${ }^{1}$
}

Fakultas Psikologi Universitas HKBP Nommensen

\begin{abstract}
There were few studies in Indonesia that had investigated the importance of personality in learning. This hypothesis of this study was there would be significance effect of the dimensions of personality based on Big Five Personality Traits Model on selfregulated learning. This study involved 342 college students. The instrument used were Big Five Personality scale and self-regulated learning scale. The result showed that $28,9 \%$ were categorized in extraversion type, $19 \%$ were categorized in conscientiousness, $17,5 \%$ in agreeableness and $14.9 \%$ were categorized in openness. Analysis of regression showed that there is significant effect of personality on self-regulated learning $\left(R=0,627 ; R^{2}=39,3 \% ; F=\right.$ $43,43 ; p$-value $<0,001)$. Further analysis showed that between five dimensions of personality, only conscienstiousness and openness that have spesific contribution on self-regulated learning. It is important then to explore the most effective strategy to improve personal characteristics such as eager to learn new things, work hard and discipline
\end{abstract}

Keywords: big five personality traits; conscientiousness; opennes; personal characteristics in learning; self-regulated learning

Abstrak. Kajian tentang dinamika kepribadian sebagai salah satu faktor yang memengaruhi perilaku belajar masih relatif minim dilakukan di Indonesia. Hipotesis yang diuji dalam penelitian ini adalah dimensi-dimensi kepribadian berdasarkan model Big Five Personality Traits dapat memprediksi self-regulated learning. Partisipan penelitian berjumlah 342 mahasiswa Universitas HKBP Nommensen. Teknik pengumpulan data menggunakan skala Big Five Personality dan skala self-regulated learning. Hasil analisis menunjukkan bahwa tipe neuroticsm mendominasi dimana ada 99 orang (28,9\%) tergolong tipe ini, disusul dengan extraversion sebanyak 67 orang (19,6\%). Selanjutnya, terdapat 65 orang $(19,0 \%)$ dengan tipe kepribadian conscientiousness, 60 orang (17,5\%) dengan tipe kepribadian agreeableness, dan yang paling sedikit adalah tipe kepribadian openness yaitu 51 orang (14.9\%). Analisis regresi menunjukkan bahwa tipe kepribadian Big Five Personality Traits ini dapat memprediksi secara signifikan terhadap self-regulated learning $\left(R=0,627 ; R^{2}=39,3 \%\right.$; $\mathrm{F}=43,43$; $p$-value $<0,001$ ) secara khusus untuk dimensi kepribadian conscienstiousness dan openness.

Kata kunci: big five personality traits; conscientiousness; karakteristik pribadi dalam belajar; opennes; self-regulated learning

Dinamika pembelajaran di perguruan tinggi yang berbeda dibandingkan di tingkat sekolah menengah menuntut mahasiswa untuk mampu melakukan pengelolaan belajar efektif dan efisien. Bagaimana mahasiswa mengelola dan mengatur pembelajarannya merupakan faktor signifikan penentu pencapaian

\footnotetext{
${ }^{1}$ Korespondensi mengenai artikel ini dapat melalui: asina.christina@hotmail.com
} 
akademiknya. Berbagai penelitian terdahulu mencoba mengeksplorasi faktorfaktor apa saja yang memengaruhi pencapaian akademik dari seorang pembelajar. Beragam hasil pun diperoleh dengan kesimpulan umum bahwa kemampuan kognitif (misal: inteligensi) tidak menjamin pencapaian akademik atau prestasi belajar. Menurut Zimmerman (dalam Schunk, 2005), pencapaian pembelajar tidak dapat secara menyeluruh dijelaskan oleh keterampilan dan kapasitas individu, melainkan ada juga peran faktor regulasi diri dan motivasi. Regulasi dalam konteks pembelajaran disebut sebagai self-regulatory learning dilihat sebagai mekanisme yang dapat menjelaskan adanya perbedaan dalam pencapaian belajar di antara para pembelajar dan juga dapat dilihat sebagai alat untuk meningkatkan pencapaian belajar. Oleh karena itu, seorang pembelajar perlu mengembangkan selfregulated learning. Menurut Pintrich (dalam Schunk, 2005) self-regulated learning adalah suatu proses konstruktif dan aktif dimana pembelajar menetapkan tujuan belajarnya dan berusaha untuk memonitor, mengelola dan mengontrol kognisi, motivasi, dan perilakunya demi mencapai tujuan yang ditetapkan. Santrock (2009) menyatakan bahwa self-regulated learning merupakan belajar mengatur diri sendiri, diantaranya adalah self-generation dan pemantauan diri (self-monitoring) dalam pikiran, perasaan, dan perilaku-perilaku untuk mencapai tujuan.

Menurut Zimmerman (2002), pembelajar dengan self-regulated learning yang tinggi adalah mereka yang aktif mengarahkan energi, kognitif, dan perilakunya dalam proses belajar. Mereka bertahan ketika menghadapi kesulitan atau tantangan dalam belajarnya. Mereka juga mencoba berbagai strategi belajar yang berbeda untuk mengoptimalkan hasil belajarnya.
Berkaitan dengan orientasi tujuan dari belajar, pembelajar dengan self-regulated learning yang tinggi cenderung berorientasi pada penguasaan tugas dimana mereka memiliki keinginan untuk memperoleh pemahaman tentang topik belajar, memilih tugas yang relatif lebih sulit, dan menggunakan strategi belajar yang lebih efektif (Susetyo \& Kumara, 2012; Tekeng \& Alsa, 2016). Mereka dapat memilih strategi belajar yang efektif, mampu mengukur sejauh mana penguasaan mereka terhadap materi belajar, memberi koreksi pada diri sendiri ketika diperlukan, dan juga menyadari pentingnya penggunaan strategi belajar (Sadeghy \& Mansouri, 2014).

Sebagai seorang staf pengajar di salah satu perguruan tinggi swasta di Kota Medan, Peneliti mengamati berbagai perilaku mahasiswa baik dalam konteks formal dan informal. Secara umum, ada saja perilaku belajar dan sikap yang kurang sesuai dengan tuntutan sebagai mahasiswa. Misalnya, mahasiswa cenderung kurang inisiatif dalam mencari tahu berbagai informasi yang relevan dengan studinya sehingga ada saja kasus dimana mahasiswa berusaha merasionalisasikan perilaku belajarnya yang tidak sesuai dengan arahan dosen, melalui pernyataan yang menyatakan tidak adanya sosialisasi mengenai perubahan jam mata kuliah misalnya. Perilaku mencontek tetap terjadi, dengan berbagai modus yang semakin tidak terduga. Perilaku mencoba mencari jalan pintas dalam mengerjakan tugas kuliah juga terjadi, misalnya alih-alih merancang bahan presentasinya sendiri, mahasiswa malah menjiplak materi presentasi dari sumber yang tidak jelas di internet. Banyak mahasiswa yang mengerjakan tugas rumah di kampus, bahkan ketika perkulihan sedang berlangsung di dalam kelas. 
Peneliti dalam berbagai kesempatan mencoba berbincang dengan beberapa orang mahasiswa mencoba mengidentifikasi berbagai kendala yang mereka alami dalam mengikuti pembelajaran. Peneliti melakukan wawancara dengan mahasiswa berinisial I.P, M.S, N.L, dan G.S pada 27 Februari 2017 yang memiliki nilai IPK <3.0. Ketika peneliti menanyakan kendala apa saja yang ditemui dalam perkuliahan. Secara umum menurut mereka ada beberapa mata kuliah yang sulit, seperti mata kuliah Psikodiagnostik, Kepribadian, Statistika dan English Psychology. Ketika ditanyakan lebih lanjut apa saja usahanya untuk menguasai materi kuliah tersebut, secara umum mereka menggunakan bertanya pada teman, namun seringkali hal itu kurang membantu karena sesama teman juga kurang menguasai. Strategi mengulang-ulang membaca dilakukan, tapi sering mengalami kendala sendiri karena kurang paham dengan apa yang dibaca. Bertanya pada dosen tidak dilakukan, karena merasa malu. Ketika ditanyakan apakah mereka memiliki jadwal belajar harian yang teratur, semua mahasiswa tersebut mengatakan mereka tidak punya rencana belajar harian, hanya belajar di rumah ketika ada tugas, atau ketika akan diadakan kuis dan ujian. Peneliti juga pernah melihat langsung hasil tugas dari para mahasiswa ini dimana tugas individual yang mereka kumpulkan kepada dosen adalah sama persis. Ternyata mereka menjiplak tugas dari teman mereka yang lain. Saat peneliti mencoba mencari tahu apa kendalanya, mereka mengatakan lupa akan deadline pengumpulan tugas, sehingga ketika mengetahui deadline tugasnya besok, maka malam sebelumnya mereka mendatangi rumah temannya untuk menjiplak hasil kerjanya. Ada juga yang mengatakan bahwa mereka tidak mengerti tugas tersebut, sehingga solusi yang dipilih adalah menjiplak hasil kerja temannya. Berbagai perilaku di atas menggambarkan lemahnya self-regulatory learning mahasiswa. Prinsip dalam selfregulated learning pada dasarnya adalah bekal bagi seorang individu untuk menjadi seorang long-life learner, pembelajar seumur hidup.

Mengingat bahwa terdapat berbagai perbedaan yang dimiliki mahasiswa dalam mengelola pembelajaran, maka dimensi kepribadian menjadi perhatian penting. Hal ini dikarenakan, unsur motivasional tampak krusial dalam pengelolaan diri untuk proses belajar. Aspek motivational individu merupakan fitur dari kepribadian yang mencerminkan kemauan/dorongan seseorang untuk bertindak (Furnham \& Chomorro- Premuzic, 2008). Beberapa hasil studi empiris menunjukkan pentingnya aspek kepribadian sebagai prediktor dalam prestasi belajar (Mularsih, 2010; Hakimi, Hejazi, \& Lavasani, 2011; Komarajju, Karau, Schmeck, \& Avdec, 2011; Buju, 2013, Hazrati-Viari, Rad, \& Torabi, 2011). O'Connor dan Paunonen (dalam HazratiViari, et al., 2011) menguraikan rasionalisasi akan peran kepribadian sebagai prediktor prestasi belajar. Pertama, terdapat kecenderungan berperilaku yang tercermin dalam kepribadian yang dapat memengaruhi kebiasaan-kebiasaan tertentu yang sangat terkait dengan pencapaian akademik seperti perseverence (ketekunan), conscientiousness (kesadaran), talkativeness (kecenderungan senang berbicara). Kedua, ketika kemampuan kogitif merujuk pada 'apa yang dapat dilakukan' oleh seorang siswa (what an individual can do), maka kepribadian merujuk pada 'apa yang akan dilakukan' siswa tersebut (what an individual will do). Ketiga, kepribadian sebagaimana kemampuan kognitif, akan dapat memprediksi pencapaian yang lebih baik pada siswa, secara khusus atribut kepribadian yang berhubungan dengan motivasi. Maka, dapat disimpulkan bahwa 
kepribadian memberi pengaruh yang unik terhadap pencapaian belajar siswa.

Oleh karena itu, peneliti tertarik mengkaji bagaimana dimensi kepribadian (dengan menggunakan model The Big Five Personality Traits) dapat memprediksi selfregulated learning. Di sisi lain, minimnya literatur penelitian dalam negeri tentang topik kajian tipe kepribadian dan prestasi belajar turut mendorong ketertarikan peneliti untuk mengeksplorasi peran kepribadian dalam peningkatan kualitas proses belajar melalui self-regulated learning. Berdasarkan penelusuran literatur imiah yang peneliti lakukan, topik ini sudah banyak diteliti, baik di negara maju maupun negara berkembang di Asia, Eropa dan Amerika Serikat (contoh: Zarafshani, Sharafi, \& Rajabi, 2011; Buju, 2013; Komarajju, Karau \& Schmeck, 2009; Komarajju et al., 2011; Chamorro-Premuzic \& Furnham, 2003) yang menunjukkan minat terhadap peran kepribadian terhadap proses dan prestasi belajar.

Berdasarkan penjelasan di atas, maka peneliti tertarik untuk melakukan penelitian dengan judul pengkajian tipe kepribadian dan hubungannya dengan selfregulated learning. Hipotesis yang diajukan adalah dimensi-dimensi kepribadian berdasarkan model Big Five Personality Traits dapat memprediksi self-regulated learning.

\section{Metode}

Variabel bebas dalam penelitian ini adalah tipe kepribadian Big Five Personality. Big Five Personality Traits adalah pengelompokan lima himpunan besar kepribadian yang dapat digunakan untuk mencari perbedaan individu berdasarkan karakteristiknya. Adapun dimensi-dimensi kepribadian berdasarkan model ini menurut McCrae \& Costa (dalam Feist \& Feist, 2008, 2010) adalah: a) Neuroticsm (neurotisme) adalah karakteristik kepribadian yang ditandai dengan dominasi oleh cemas, kehadiran emosi yang negatif seperti rasa khawatir, tegang, dan takut. b) Opennes (terbuka terhadap pengalaman) adalah karakteristik kepribadian yang ditandai dengan keterbukaan wawasan dan orisinal ide, menyukai berbagai informasi baru, senang belajar hal-hal yang baru. c) Extraversion (ekstraversi) adalah karakteristik kepribadian yang ditandai dengan adanya semangat dan keantusiasan. d) Conscientiousness adalah karakteristik kepribadian yang ditandai dengan bersungguh-sungguh dalam melakukan tugas, bertanggung jawab, dapat diandalkan, dan menyukai keteraturan dan kedispilinan. e) Agreeableness (kebersetujuan) adalah karakteristik kepribadian yang ditandai dengan memiliki ciri-ciri ketulusan dalam berbagi, kehalusan perasaan, serta fokus pada hal-hal positif dari orang lain.

Variabel tergantung/terikat dalam penelitian ini adalah self-regulated learning. Self-regulated learning adalah persepsi pembelajar tentang proses regulasi dalam kegiatan belajarnya. Untuk mengungkap self-regulated learning digunakan Motivated Strategies for Learning Questionnaire (MSLQ) yang dikembangkan oleh Pintrich, Smith, Garcia, \& Mckeachie (1991). Sampel penelitian sebanyak 342 orang mahasiswa aktif dari berbagai program studi di Universitas HKBP Nommensen.

\section{Skala big five personality}

Skala Big Five Personality dalam penelitian ini diadaptasi dari Oliver's Big Five Inventory yang berbahasa Inggris yang telah diterjemahkan dalam Bahasa Indonesia dan sudah dilakukan uji validitas dan reliabilitas oleh Sianipar (2008). Skala ini terdiri dari 76 aitem dengan distribusi aitem seperti pada Tabel 1. 
Tabel 1

Distribusi aitem-aitem skala Big Five Personality

\begin{tabular}{lllc}
\hline \multicolumn{2}{c}{ Dimensi } & \multicolumn{1}{c}{ Nomor aitem } & Jumlah \\
\hline Extraversion & Favorable & $1,11,16,26,36,45,56,70,73,75$ & 16 \\
& Unfavorable & $6,21,26,51,62,68$ & \\
Agreeableness & Favorable & $7,17,22,32,42,46,52,57,63,76$ & 16 \\
& Unfavorable & $2,12,27,37,69,74$ & \\
Conscientiousness & Favorable & $3,13,28,33,38,53,58,64$ & 13 \\
& Unfavorable & $8,18,23,43,47$ & 13 \\
Neuroticsm & Favorable & $4,14,19,29,39,59,71$ & \\
& Unfavorable & $9,24,34,48,54,65$ & 18 \\
Openness & Favorable & $5,10,15,20,25,30,40,44,49,50,55,60,66,67,72$ & \\
& Unfavorable & $35,41,61$ & 76 \\
\hline
\end{tabular}

Dalam skala ini disediakan empat pilihan jawaban yang mengacu pada tingkat kesesuaian dengan keadaan partisipan penelitian yang mengisi skala tersebut. Pilihan jawaban tersebut adalah: Sangat Tidak Sesuai (STS), Tidak Sesuai (TS), Kurang Sesuai (KS), Cukup Sesuai (CS), Sesuai (S), dan Sangat Sesuai (SS). Bobot penilaiannya bergerak dari angka 1 sampai 6 untuk aitem favourable dan unfavourable. Sianipar (2008) telah menguji reliabilitas skala ini dan diperoleh hasil koefisien Alpha Cronbach antara 0.71 sampai 0.82. Kemudian, Ramdhani (2012) telah melakukan penelitian tentang reliabilitas alat ukur ini dan hasilnya adalah nilai koefisien Alpha Cronbach antara 0.73 sampai 0.79 .

\section{Skala self-regulated learning}

Pengukuran self-regulated learning menggunakan Motivated Strategies for Learning Questionnaire (MSLQ) yang dikembangkan oleh Pintrich, et al. (1991). Skala ini dirancang untuk mengukur orientasi motivasi dan penggunaan strategi pembelajaran mandiri dalam konteks pendidikan tinggi (Pintrich, Smith, Garcia,
Mckeachie (1993) dengan koefisien Alpha Cronbach antara 0.52 sampai 0.80 (Duncan, McKeachie, 2005). Dalam skala ini disediakan empat pilihan jawaban yang mangacu pada tingkat kesesuaian dengan keadaan partisipan penelitian yang mengisi skala tersebut. Pilihan jawaban tersebut adalah: Sangat Tidak Sesuai (STS), Tidak Sesuai (TS), Kurang Sesuai (KS), Cukup Sesuai (CS), Sesuai (S), dan Sangat Sesuai (SS). Bobot penilaiannya bergerak dari angka 1 sampai 6 untuk aitem favourable dan unfavourable. Data yang diperoleh telah dianalisa dengan menggunakan teknik analisis regresi sederhana dengan menggunakan bantuan program analisis Statistical Product and Service Solution (SPSS) for windows 16.

\section{Hasil}

Analisa deskriptif terhadap data yang diperoleh berkaitan dengan bagaimana gambaran distribusi dari tipe kepribadian Big Five Personality bila ditinjau dari jenis kelamin. Rangkuman hal tersebut tersaji dalam Tabel 2. 


\section{ROSITO}

Tabel 2.

Gambaran sampel penelitian berdasarkan jenis kelamin dan tipe kepribadian

\begin{tabular}{ccccccc}
\hline \multicolumn{1}{c}{ JK } & Neuroticsm & Ekstraversion & Conscientiousness & Agreeableness & Openness & Total \\
\hline Laki-laki & $32 / 23,8 \%$ & $25 / 18,6 \%$ & $26 / 19,4 \%$ & $30 / 22,3 \%$ & $21 / 15,6 \%$ & 134 \\
Perempuan & $67 / 32,2 \%$ & $42 / 20,1 \%$ & $39 / 18,7 \%$ & $30 / 14.4 \%$ & $30 / 14,4 \%$ & 208 \\
\hline Total & 99 & 67 & 65 & 60 & 51 & 342 \\
\hline
\end{tabular}

Berdasarkan informasi pada Tabel 2, bisa disimpulkan bahwa mahasiswa perempuan lebih banyak yang tergolong pada tipe kepribadian neuroticsm dan ekstraversion. Sementara itu, mahasiswa laki-laki lebih banyak yang tergolong pada tipe kepribadian conscientiousness, agreeableness, dan openness. Analisa deskriptif selanjutnya berkaitan dengan bagaimana gambaran distribusi dari tipe kepribadian Big Five Personality bila ditinjau dari program studi sampel penelitian. Rangkuman hal tersebut tersaji dalam Tabel 3.

Hipotesis utama dalam penelitian ini adalah dimensi-dimensi kepribadian berdasarkan model Big Five Personality traits dapat memprediksi self-regulated learning. Berdasarkan hasil analisis regresi sederhana, diperoleh bahwa nilai $\mathrm{F}=43,43$ dan signifikan pada $p$-value $<0,001$. Hal ini berarti bahwa model regresi yang dihasilkan ini, secara keseluruhan, dapat memprediksi self-regulated learning. Berdasarkan analisis korelasi, diperoleh nilai $\mathrm{R}$ sebesar 0,627 yang menunjukkan adanya korelasi positif antara tipe kepribadian Big Five Personality dan self-regulated learning. Nilai $\mathrm{R}^{2}=0,393$ yang diperoleh dari analisa data menunjukkan bahwa variasi dalam selfregulated learning dapat dijelaskan sebesar 39,3\% dari variasi tipe kepribadian Big Five Personality. Dengan kata lain, 60,7\% variasi dalam self-regulated learning tidak dapat dijelaskan oleh tipe kepribadian Big Five personality. Artinya, ada variabel lainnya yang memengaruhi self-regulated learning selain tipe kepribadian ini.

Tabel 3.

Gambaran sampel penelitian berdasarkan program studi dan tipe kepribadian

\begin{tabular}{lcccccc}
\hline \multicolumn{1}{c}{ Program Studi } & $\begin{array}{c}\text { Neuro- } \\
\text { ticsm }\end{array}$ & $\begin{array}{c}\text { Ekstra- } \\
\text { version }\end{array}$ & $\begin{array}{c}\text { Conscien- } \\
\text { tiousness }\end{array}$ & $\begin{array}{c}\text { Agree- } \\
\text { ableness }\end{array}$ & Openness & Total \\
\hline Manajemen & 19 & 9 & 6 & 19 & 7 & 51 \\
Ekonomi Pembangunan & 7 & 5 & 1 & 7 & 3 & 22 \\
Psikologi & 12 & 4 & 10 & 12 & 3 & 31 \\
Hukum & 7 & 18 & 16 & 7 & 8 & 63 \\
Agribisnis & 14 & 7 & 7 & 14 & 4 & 35 \\
Sastra Inggris & 6 & 2 & 1 & 6 & 6 & 17 \\
Pendidikan Bahasa Inggris & 10 & 5 & 6 & 10 & 5 & 31 \\
Pendidikan Ekonomi & 9 & 3 & 9 & 9 & 2 & 27 \\
Pendidikan Matematika & 6 & 7 & 7 & 6 & 10 & 37 \\
Pendidikan Bahasa Indonesia & 9 & 7 & 2 & 9 & 3 & 28 \\
\hline \multicolumn{1}{c}{ Total } & 99 & 67 & 65 & 60 & 51 & 342 \\
\hline
\end{tabular}


Dengan demikian, dapat disimpulkan bahwa hipotesis utama yang diajukan dalam penelitian ini diterima, yaitu terdapat pengaruh yang signifikan dari tipe kepribadian Big Five Personality terhadap self-regulated learning. Beberapa hipotesis spesifik pada penelitian ini adalah sebagai berikut. 1) Terdapat peran negatif dimensi neuroticism terhadap self-regulated learning; 2) Terdapat peran positif dimensi agreeableness terhadap self-regulated learning; 3) Terdapat peran negatif dimensi extraversion terhadap self-regulated learning; 4) Terdapat peran positif dimensi openness terhadap self-regulated learning; 5) Terdapat peran positif dimensi conscientiousness terhadap self-regulated learning. Untuk menguji beberapa hipotesis spesifik tersebut, analisis regresi lanjutan menunjukkan model parameter dan nilai signifikansi untuk masing-masing dimensi kepribadian, seperti yang terangkum dalam Tabel 4.

Tabel 4.

Hasil analisis regresi untuk masing-masing dimensi kepribadian dalam Big Five Personality terhadap self-regulated learning

\begin{tabular}{lcc}
\hline \multicolumn{1}{c}{ Dimensi } & $\mathrm{B}$ & $p$ \\
\hline Neuroticsm & 0,17 & 0,21 \\
Agreeableness & 0,26 & 0,15 \\
Extraversion & 0,12 & 0,43 \\
Openness & $0,69^{* *}$ & 0,00 \\
Conscientiousness & $1,62^{* *}$ & 0,00 \\
\hline
\end{tabular}

Note. $\mathrm{N}=342 . ; \quad{ }^{* *} \mathrm{p}<.01$

Berdasarkan hasil analisis regresi untuk menguji kontribusi masing-masing dimensi kepribadian terhadap self-regulated learning dalam model regresi yang dihasilkan, seperti yang terangkum dalam Tabel 4, maka dapat disusun kesimpulan sebagai berikut. 1) Dimensi kepribadian neuroticsm tidak berperan terhadap selfregulated learning. Hal ini dikarenakan hasil analisis regresi menunjukkan $\beta$-value $=$
0,$174 ;$-tes value $=1,244 ;$ dan $p$-value $>0,5$. Dengan demikian hipotesis spesifik yang pertama ditolak; 2) Dimensi kepribadian agreeableness tidak berperan terhadap selfregulated learning. Hal ini dikarenakan hasil analisis regresi menunjukkan $\beta$-value $=$ 0,$265 ;$ tes value $=1,424$; dan $p$-value $>0,5$. Dengan demikian hipotesis spesifik yang kedua ditolak; 3) Dimensi kepribadian extraversion tidak berperan terhadap selfregulated learning. Hal ini dikarenakan hasil analisis regresi menunjukkan $\beta$-value $=$ 0,$124 ;$ t-tes value $=0,782$; dan $p$-value $>0,5$. Dengan demikian hipotesis spesifik yang ketiga ditolak; 4) Dimensi kepribadian openness berperan terhadap self-regulated learning. Hal ini didukung oleh hasil analisis regresi yang menunjukkan $\beta$-value $=$ 0,$692 ; t$-tes value $=4,466$; dan $p$-value $<0,001$. Dengan demikian hipotesis spesifik yang keempat diterima; 5) Dimensi kepribadian conscientiousness berperan terhadap selfregulated learning. Hal ini diperoleh dari hasil analisis regresi yang menunjukkan $\beta-$ value $=1,620$; $t$-tes value $=8,831$; dan $p$-value $<$ 0,001 . Dengan demikian hipotesis spesifik yang kelima diterima.

\section{Diskusi}

Tujuan penelitian ini adalah; 1) mengetahui gambaran kepribadian berdasarkan model Big Five Personality Traits Theory pada mahasiswa Universitas HKBP Nommensen, 2) mengetahui gambaran selfregulated learning pada mahasiswa Universitas HKBP Nommensen, dan 3) mengetahui apakah terdapat pengaruh kepribadian berdasarkan model Big Five Personality Traits Theory terhadap selfregulated learning.

Berdasarkan hasil analisa deskriptif terhadap 342 orang mahasiswa aktif Universitas HKBP Nommensen, yang tersebar dari berbagai program studi, 
diperoleh gambaran bahwa tipe kepribadian yang paling banyak adalah tipe kepribadian neuroticsm, yaitu sebanyak 99 orang $(28,9 \%)$, disusul dengan tipe kepribadian extraversion dengan 67 orang $(19,6 \%)$, kemudian tipe kepribadian conscientiousness sebanyak 65 orang $(19,0 \%)$, lalu tipe kepribadian agreeableness sebanyak 60 orang $(17,5 \%)$ dan yang paling sedikit adalah tipe kepribadian openness yaitu sebanyak 51 orang (14,9\%). Penelitian senada pernah dilakukan oleh Rosito \& Ambarita (2016) pada satu siswa SMU Swasta di kota Medan dimana penelitian tersebut bertujuan untuk mengetahui apakah terdapat korelasi antara kepribadian dengan model Big Five Personality Traits dengan prestasi akademik pada siswa remaja. Hasil dari analisis deskripsi menunjukkan bahwa sebagian besar siswa $(27,9 \%)$ tergolong dalam tipe kepribadian neuroticsm. Kesamaan dalam kedua penelitian ini adalah hampir keseluruhan dari partisipan penelitian berlatar belakang suku Batak. Dominasi dalam tipe kepribadian neuroticsm ini dapat dikaitkan dengan budaya dari Suku Batak itu sendiri. Dewi (2004) dalam penelitiannya menemukan adanya perbedaan yang signifikan mengenai anteseden kemarahan interpersonal, trait anger, anger in expression-in, anger expression control-out, dan anger expression control-in pada orang Batak dan orang Jawa. Orang Batak terlihat ekspresif dalam mengungkapkan rasa marahnya dan trait anger cukup sering muncul terutama pada laki-laki. Pola-pola perilaku khusus yang tampak dari suku bangsa Batak dapat menggambarkan kepribadian mereka. Pola-pola perilaku tersebut dipengaruhi oleh nilai-nilai dari suku bangsa itu sendiri.

Dimensi neuroticsm berhubungan dengan dua emosi dasar yaitu fear (rasa takut) dan angry (rasa marah). Individu yang dominan pada dimensi ini bersifat nervous, high-strung, tense, worried, pessimistic, anxious, temperamental, self-pitying, self-conscious, emotional dan vulnerable to stress related disorders. Individu mudah marah dan cenderung sulit bersama orang lain untuk waktu yang lama. Pola karakter ini secara umum dikenal sebagai ciri dari individu dengan latar belakang budaya Batak, dimana orang Batak dikenal temperamental, impulsif, cemas, dan rentan terhadap stres, dan lainnya yang merupakan gambaran dari tipe kepribadian neuroticsm. Berbagai emosi negatif tersebut dapat menghambat regulasi belajar individu dan motivasi untuk belajar (Mega, Ronconi, \& De Beni, 2014).

Berdasarkan hasil analisa deskriptif terhadap variabel self-regulated learning, dapat dilihat bahwa secara umum kondisi self-regulated learning mahasiswa Universitas HKBP Nommensen berada pada kategori sedang. Hal ini diketahui dari perbandingan antara mean hipotetik dan mean empirik, dimana selisihnya hanya sedikit (sebesar 1.5 poin) sehingga termasuk kategori sedang. Self-regulated learning merupakan konsep penting yang berorientasi pada pengembangan kapasitas seorang individu dalam mengelola pembelajarannya dengan berorientasi pada pencapaian tujuan belajar (Zimmerman, 2008). Bandura (dalam Fasikhah \& Fatimah, 2013), menyatakan bahwa selfregulated learning yaitu proses di mana seseorang dapat mengatur pencapaian dan aksi mereka sendiri dengan menentukan target, mengevaluasi kesuksesan seseorang saat mencapai target dan memberikan penghargaan karena sudah mencapai tujuan tertentu.

Hasil penelitian ini menunjukkan bahwa secara keseluruhan terdapat peran yang signifikan dari kepribadian terhadap self-regulated learning. Hal ini menunjukkan 
bahwa pola-pola perilaku yang menetap dalam diri individu (dalam hal ini disebut dengan kepribadian), dengan dimensi neuroticsm, extraversion, openness, agreeableness dan conscientiousness, dapat menjadi salah satu prediktor yang akurat akan kapasitas individu dalam mengelola pembelajarannya yang berbasis pada tujuan. Secara spesifik, diketahui juga dari hasil penelitian ini bahwa dari antara lima dimensi kepribadian tersebut, ada dua dimensi yang berperan secara spesifik terhadap self-regulated learning yaitu dimensi conscientiousness dan openness.

Dimensi conscientiousness berasosiasi dengan perilaku disiplin, pekerja keras, teratur, tertib, seperti merencanakan dan mengorganisir tugas, berperilaku dengan rasa tanggung jawab dan berambisi untuk sukses di bidang akademik. Individu dengan kategori kepribadian conscientiousness menjadi variabel prediktor yang sangat signifikan bagi keberhasilan individu dalam mencapai prestasi belajar di bangku sekolah menengah dan di perguruan tinggi (Surna-Pandeirot, 2014). Dalam mengembangkan self-regulated learning, dimensi ini sangat terkait, karena self-regulated learning menuntut kesadaran individu akan perlunya tujuan, perencanaan, monitoring dalam mengarahkan perilakunya dalam konteks pembelajaran. Sehingga, semakin tinggi dimensi ini dalam kepribadian individu, maka akan semakin tinggi kapasitas individu tersebut dalam regulasi belajarnya.

Dimensi openness mengacu pada aspek kreatif dan inovatif dari seseorang, dimana pribadi secara konsisten mencari pengalaman berbeda dan beragam. Individu yang tinggi dalam dimensi ini cenderung proaktif dalam melakukan pencarian, memiliki rasa ingin tahu yang tinggi, dan menghargai pengalaman untuk diri sendiri. Mereka cenderung mampu melakukan penyesuaian pada suatu ide atau situasi yang baru. Seseorang dengan tingkat openness yang tinggi digambarkan sebagai seseorang dengan nilai creative, imaginative, curious, liberal, dan have a preference for variety. Mereka cenderung konsisten dalam mencari pengalaman yang berbeda dan bervariasi. Dimensi ini diperlukan dalam mengelola pembelajaran dimana self-regulated learning menuntut individu untuk bersedia mencari tahu dan mempelajari berbagai sumber daya belajar yang dapat dimanfaatkan untuk peningkatan kemampuan belajarnya. Selain itu, inisiatif dalam mencari bantuan baik dari guru, teman, atau orang dewasa lainnya sebagai bentuk dari keterbukaan terhadap pengalaman dan terhadap orang di sekitarnya, dapat membantu individu untuk meningkatkan pencapaian tujuan pembelajarannya.

\section{Kesimpulan}

Berdasarkan hasil uji hipotesis utama dengan menggunakan analisa regresi, diperoleh hasil bahwa secara umum, model regresi yang dihasilkan menunjukkan bahwa kepribadian dengan model Big Five Personality Traits ini memberikan pengaruh signifikan terhadap self-regulated learning. Berdasarkan hasil uji regresi selanjutnya yang melihat secara spesifik kontribusi dan signifikansi dari tiap dimensi kepribadian, diperoleh hasil bahwa terdapat dimensi kepribadian conscienstiousness dan openness berperan terhadap self-regulated learning.

\section{Saran}

Bagi penelitian selanjutnya, dapat lebih mengkaji sejauh mana unsur kebudayaan memengaruhi tipe kepribadian dan dampaknya pada self-regulated learning. Untuk itu, perlu memperluas cakupan penelitian ke populasi dari latar belakang 
budaya lainnya seperti suku Jawa, suku Sunda, dan lainnya.

\section{Kepustakaan}

Buju, S. (2013). Personality profile of students with technical academic performance. Procedia-Social and Behavioral Science, 78, 56-60.

Chamorro-Premuzic, T. \& Furnham, A. (2003). Personality traits and academic examination performance. European Journal of Personality, 17, 237-250. doi: 10.1002/per.473

Dewi, Z. L. (2004). Antesenden, pengalaman, ekspresi, dan kontrol marah pada orang Batak dan orang Jawa (Tesis). Depok: Program Pascasarjana Fakultas Psikologi Universitas Indonesia.

Duncan, T. C., \& McKeachie, W. J. (2005). The making of the motivated strategies for learning questionnaire. Educational Psychologist, 40(2), 117-128. doi: 10.12 07/s15326985ep4002_6

Fasikhah, S. S. \& Fatimah, S. (2013). Selfregulated learning (SRL) dalam meningkatkan prestasi akademik pada mahasiswa. Jurnal Ilmiah Psikologi Terapan, 1(1), 145-155. doi: 10.22219/ jipt.v1i1.1364

Feist, J. \& Feist, J. G. (2008). Teori kepribadian (ed. 6). Yogyakarta: Pustaka Belajar.

Feist, J. \& Feist, J. G.(2010). Teori kepribadian (Buku 2). Jakarta: Penerbit Salemba Humanika.

Furnham, A. \& Chamorro-Premuzic, T. (2008). Personality, intelligence and approaches to learning as predictors of academic performance. University College London: Elsevier.

Hakimi, S., Hejazi, E., \& Lavasani, M. G. (2011). The relationship between personality traits and students' academic achievement. Procedia-Social and Behavioral Science, 29, 836-845. doi: 10.1016/j.sbspro.2011.11.312

Hazrati-Viari, A., Rad, A. T., \& Torabi, S. S. (2011). The effect of personality traits on academic performance: The mediating role of academic motivation. Procedia-Social and Behavioral Science, 32, 367-371. doi: 10.1016/j.sbspro.2012. 01.055

Komarraju, M., Karau, S. J., \& Schmeck, R. R. (2009). Role of the Big five personality traits in predicting college students' academic motivation and achievement. Personality and Individual differences, 19, 47-52. doi: 10.1016/ j.lindif.2008.07.001

Komarraju, M., Karau, S. J., Schmeck, R. R., \& Avdic, A. (2011). The Big five personality traits, learning styles, and academic achievement. Personality and Individual Differences, 51, 472-477. doi: 10.1016/j.paid.2011.04.019

Mega, C., Ronconi, L. \& De Beni, R. (2014). What makes a good student? How emotions, self-regulated learning, and motivation contribute to academic achievement. Journal of Educational Psychology, 106(1), 121-131. doi: 10. 1037/a0033546.

Mularsih, H. (2010). Strategi pembelajaran, tipe kepribadian dan hasil belajar Bahasa Indonesia pada siswa Sekolah Menengah Pertama. Makara, Sosial Humaniora, 14(1), 65-74. doi: 10.7454/ mssh.v14i1.573

Pintrich, P. R., Smith, D. A. F., Garcia, T., \& Mckeachie, W. J. (1991). Manual for the Use of Motivated Strategies for Learning Questioonaire (MSLQ). USA: National Centre for Research to Improve Postsecondary Teaching and Learning.

Pintrich, P. R., Smith, D. A. F, Garcia, T., Mckeachie, W. J. (1993). Reliability and predictive validity of the Motivated 
Strategies for Learning Questionnaire (MSLQ). Educational and Psychological Measurement, 53, 801-813. doi: 10.1177/ 0013164493053003024

Rosito, A. C. \& Ambarita, T. F. A. (2016). Pengkajian tipe kepribadian dan hubungannya dengan prestasi belajar pada siswa Sekolah Menengah Atas. Jurnal Psikologi Universitas HKBP Nommensen, 3(1), 39-64.

Sadeghy, A. R. \& Mansouri, A. (2014). The relationship between learners' goal oriented and self-regulated learning and their endorsement of L2 learning strategies. International Journal of Language Learning and Applied Lingustics World, 5(2), 574-593.

Santrock, J. W. (2009). Psikologi pendidikan (ed. 3). Jakarta: Salemba Humanika.

Schunk, D. H. (2005). Self-regulated learning: The educational legacy of Paul R. Pintrich. Educational Psychologist, 40, 85-94. doi: 10.1207/ s15326985ep4002_3

Sianipar, S. (2008). Gambaran kepribadian suku bangsa batak Toba menggunakan Big Five Inventory. Naskah tidak dipublikasikan. Universitas Sumatera Utara, Medan.

Surna, I. N. \& Pandeirot, O. D. (2014).
Psikologi pendidikan. Jakarta: Penerbit Erlangga

Susetyo, Y. F., \& Kumara, A. (2012). Orientasi tujuan, atribusi penyebab, dan belajar berdasar regulasi diri. Jurnal Psikologi UGM, 39(1), 95-111. doi: 10.22146/jpsi.6969

Tekeng, N. Y., \& Alsa, A. (2016). Peranan kepuasan kebutuhan dasar psikologis dan orientasi tujuan mastery approach terhadap belajar berdasar regulasi diri. Jurnal Psikologi UGM, 43(2), 85-106. doi: 10.22146/jpsi.22856

Zarafshani, K. Sharafi, L., \& Rajabi, S. (2011). Using the Myers-Briggs Type Indicator (MBTI) in the teaching of entrepreneurial skills. International Journal of Science and Technology Education Research, 2(4), 66-74.

Zimmerman, B. J. (2002). Becoming a selfregulated learner: An overview. Theory into Practice, 41, 64-70. doi: 10. 1207/s15430421tip4102_2

Zimmerman, B. J. (2008). Investigating selfregulation and motivation: Historical background, methodological developments, and future prospects. American Educational Research Journal, 45, 166-183. doi: 10. 3102/ 0002831 207312909 